DOI: 10.24234/wisdom.v15i2.367

Lesya SYNIAVSKA, Viktoriia KOLKUTINA, Volodymyr POHREBENNYK

\title{
TEXT-TRANSFORMS - COMMUNICATIVE PARADIGM BASIS OF A LITERARY WORK
}

\begin{abstract}
The article introduces and investigates the concept of a "text-transform" based on the novel and shortnovel plots of the drama works of the Ukrainian dramatists of the late $19^{\text {th }}-$ early $20^{\text {th }}$ centuries. The texttransform is defined as a message by a different author, with a different structure, different code, composition, and fable, sometimes, with a different system of images. This research paper also looks at the different levels of transformations: dramatisation, adaptation, and creation of a play, based on a literary work. The early $20^{\text {th }}$ century sees actualisation of the strategy of transformed communication, when in the process of transformation of the narrative elements, dramatists exploit the strategy of preservation, shortening, expanding, and changing text blocks. It is determined by the theatre-specific process and pragmatic orientation on the stage performance. Meanwhile, extension and changes that a text-reference is subject to are aimed to explicate and intensify the current and preserved relationships between characters in texttransforms.
\end{abstract}

Keywords: artistic communication, communicative paradigm, text, text-transform, text-reference.

Introduction

Text-transforms and the concept of the text's "communicative paradigm", in our opinion, have an interdisciplinary nature. As a philological concept, the text's communicative paradigm can also be projected on humanitarian knowledge: philosophy, art, fine art, and the others. It generates a multi-faceted approach to the text studies, which implies the application of general philosophical methods as well as the principles of the methodological basis of other sciences.

The integration of this concept into the philosophical discourse of the Modernism era, which was a foundation of people's existence in the late $19^{\text {th }}$ - early $20^{\text {th }}$ centuries, contributes to comprehensive studies of literature.

Recently, philosophical inquiries see a significant number of works, which establish the fact of the dialogue between the various areas of scientific knowledge. For example, the philosopher V. Stiopin emphasises that the scope of socio-humanitarian sciences comprises a humanbeing and her / his consciousness. Quite often, it is presented as a text with the meaning, imposed by a human. Meanwhile, the fixation of this scope and its further research require specific methods and "cognitive procedures". Such cognitive procedures can be distinguished as a result 
of creating a communicative paradigm of the text through the application of philosophical methods. They contribute to broadening this paradigm and transporting it to other areas of the art, exploiting the symbols of other semiotic systems.

When dipping in the specific nature of the short-novel and novel's plots of the Ukrainian dramaturgy, it is relevant to introduce the concept of a communicative transform of a work of fiction. These transforms are defined as the communicative entities (primarily but not limited to the written texts), "which reveal their own identity, associated with an original artwork - an original text (preserving the title and author's surname); however, in fact, these messages are targeted at a different addressee and have a different structure or even a different code" (Kolehaieva, 2000 , p. 547). The analysis of the variety of the possible paradigms, which may comprise a work of fiction, suggests that "a text, seen as a complete and finalised verbal message, may acquire an individual paradigm of its own, resulting from the compressive, diminutive, or, on the contrary, expansive and expanding transformations" (Kolehaieva, 2008, p. 77).

We fully agree with this idea and would like to add the following: this process also includes transformations at the level of structure, genre, text type, imagery, social and moral perception of the text and the author's image. The unity of all the elements - "of the original text and all its transforms - creates a communicative paradigm of the work" (Kolehaieva, 2000, p. 547). The transforms of a work of fiction include not only its adapted versions for young readers or beginner foreign readers, digests of the work or, on the contrary, the versions supplied with a foreword, afterword, or non-author's comments for a culturally unenlightened reader (for instance, the revised editions of a $19^{\text {th }}$-century piece with the comments for $21^{\text {st }}$-century readers) but also "transcoding" and "cross-coding" (Kolehaieva, 2000, pp. 548-549) transformations. They refer to the translations into other languages or adaptation of works of fiction into other semiotic systems, such as films or theatre production.

This paper aims to characterise the transforms in terms of the communicative theory, which exposes unique opportunities and capabilities of integration and taking over such texts and their perception as communicative works.

\section{Results and Discussion}

In our case, a work of fiction is transformed by the symbols of a different semiotic system, specifically, drama; therefore, we suggest the following communicative model for analysing such transforms:

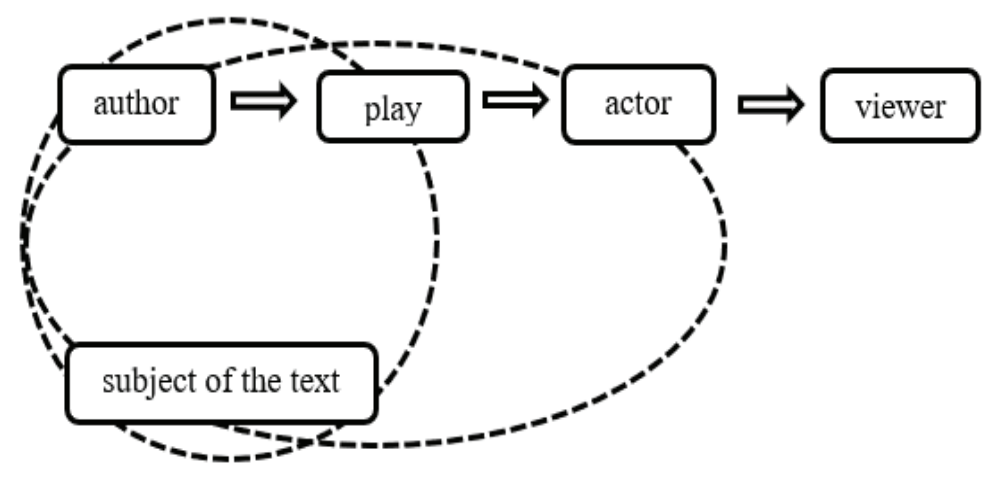

Image 1. 
As we can see, in texts-transforms, a reader simultaneously acts as the author of the play, too, as she is integrating the functions of both an addresser and recipient of the text - two rolled in one. So, the author's image can be seen as a heterogeneous feature of such texts-transforms. "The author's image is a cross-cutting image of the work; it is its deep consolidating element, which secures the integration of the separate pieces into one entity and charges it with the single consciousness, single world view, and single perception of reality", says V. Kukharenko (2002).

The author's image, however, should not be equated to the writer's personality. The term "an author" often means a particular view on reality, and not so rarely, it takes an entire work of fiction to deliver it. The fiction image of the author is often based on the reality perception, philosophic principles, and a creative concept of the writer. When the real author is creating a fictitious image of the author in the play, her or his real-life circumstances may undergo changes. The author's image, along with the characters' images, is integrated into the structure of the work of fiction. Still, if compared to the textreference, the author's image is also modified in the texts-transforms. As a result, such texts establish a new "principle of distribution of the roles", which makes it possible to track down the role, played by someone who is speaking: a guide, ordinary person, member of the community, etc.

The sequence of language characters becomes a text-statement once someone re-directs it to someone else with a communicative intention. Not every text mentions the message's addresser or addressee that introduces them thematically. However, they can always be presented implicitly. The information about them (an addresser and addressee) is implied in the speaking mode itself, which may contrast with a communicative situation - the one inherited in the text and actually realised. Every thematised situation is subject to verification through the implicit information - it gets either endorsed or disputed.

Therefore, every "I" - pattern, systematised in the message (either presented or subjectified), has a building-up perspective of the implied "I": a subjective reflection of a sender in their own speech" (Riffaterre, 1980, p. 113). The sender can openly address one person while making someone else an addressee by shaping and localising her or his speech. In this case, the implicit information refers to the addressee other than the one mentioned in the text. It is the reason why communicative transforms reproduce at least two types of relations between the addresser and recipient and make them use different communicative strategies during their interaction. When a dramatic text is functioning as a readable text, the author remains the only actual addresser of dialogues in the reader's perception. In the stage version, this role is distributed among the author and the actors. Therefore, we can speak about the transformation of the message addresser in the stage transform, even though the author speaks from themselves and it is quite apparent that this is not an external author but a uniquely constructed text item. The classification distinguishes at least four typical situations of how the author's image is represented in the dramatic text, namely: 1) a biographical author. The real author steps into the literary fiction area as a "subject of imagination" (according to Ingarden). It is kind of a disguise, a mask; 2) a potential author. The author in the text of the message is present immanently, i.e. the author's image is reconstructed through the constructive analysis of the creative subject, performed by a recipient. This author is revealed in the text construction 
through the choice of events, composition, the concepts of time and space. The image of the potential author can provide the text with the meanings which were not initially implied. It is fair to assume that this image is related to the concept of the communicative paradigm of the work of fiction; 3) self-presentation. The author shows the ways of arranging the stage action. Self-presentation is most often displayed in the metatext phenomena of the construction "theatre inside of the theatre". The author's presentation is, in fact, a metatext - a supratext built above the subjective texts; 4) an implicit author. According to E. Bolkutsanu, this author is an implementor of such textual operations as the title, genre reference, epigraph, and narration. The implicit author is defined as a subject which carries out textual operations as a correlative of norms and rules, established in the statement. Personally, he is presented as an individual with the implied characteristics of the text-transform or the one who is revealed through the self-representative information (Belcerzan, 2002).

The text is always someone's verbal product and, through the way of its arrangement, it never fails to communicate the "pattern" of its acting subject. The latter, however, is not identical to either the presented first-person narrator or to the implied narrator, who presents a third-person character. Both of them, despite differences between the addresser and addressee, are the similarly fictitious semantic textual constructions subject to the linguistic and literary rules, applied for the work of fiction. Both of them are governed by the superior (acting) subject of the work.

To sum it up, the following should be emphasised: the author in the drama is " $\mathrm{I}$ ", who represents the drama text, constructs the dialogues, arranges narration, decides on how the fable is going to develop, focuses the recipients' attention, releases or heightens tension, enables to perceive the reality in compliance with the poetics, accepted by him. The author displays his power over the world he created explicitly and implicitly, indirectly and directly. The author's position is represented through the characters' phrases as a creative consciousness that guides them. All these forms of the author's presence allow for more in-depth and more comprehensive analysis of the author's image in the dramatic text. The author's image, being a part of the text, is an essential component for the comprehensive understanding and perception of the drama text as it makes it more consolidated and complete.

The diverseness of the author's representation in this text opens the way to establishing the connection between the element (author's image) with others and its function in the philosophic and artistic system of the work. The author's image in the text becomes a subject of the speech, i.e. the one depicting and describing. The subject of speech in prose fiction is different from that of the dramatic one. In prose works, the subject of the speech is presented by a narrator, personal narrator, and story-teller (Korman, 1971, p. 9). In dramatic work, though, the author's presence is reproduced in two ways: narrative-and-compositional and verbal (Korman, 1977).

In the former, the author communicates his presence in the text by bringing the parts into correlations while in the latter, it is executed through the characters' speech. It gives us the reason to affirm that the author does not only create but also represents the text, and his voice can be heard in the characters' lines. Therefore, the author is "I", which both presents and creates the text concurrently. His voice sounds in the characters' voice. A dramatic dialogue is formed 
based on the continuous game between a word as a means of communication between the characters and a work targeted at the viewer and addressed to them.

Concerning the viewer, the author can also express his stand in the comments, and the author's alter ego and choir parts. All of these are the explicit forms of the display of the author's position in the text. However, there are also the implicit forms of such display: the text which seemingly does not relate to the dialogue; the text addressed not at the stage partner but rather at a specific abstract, generalised image of the viewer. Such text, often by using the characters as agents, communicates the ideas of the dramatic work author. Meanwhile, the stage directions, the list of characters, instructions for actors and script-writers are supplemental.

Besides the transformation of the author's image into the text subject and various ways of his representation and presence in the text of the transform, there is also a modification of the ways to actualise the conflict of the work. The conflict may remain unchanged from what it was in the text-reference; however, the means and ways to actualise it may vary considerably. For instance, in the dramatic texts, the conflict is concentrated in the dialogues as it develops within them. The social environment can also become the transmitter of such conflict. Transformations of the novel's conflict in the dramatic texts-transforms may undergo in two ways: the particularisation of specific plot lines and twists and selection of a separate plotline of the original text, i.e. its actualisation. Here, the text of the transform may undergo significant changes both at the level of the text and the level of the work's image system.

The transition of the novelistic text into the dramatic one enables us to speak about different levels of their transformation, in particular, dramatisation and adaptation. Moreover, a work of fiction may be based on the other work; the same may be relevant for the play either. The dramatisation is an accurate communication of the plot and characters utilising means of drama. In this case, we can speak about the thematical identity of the text-transform and the text of the novel. In this case, the content-and-factual information is preserved; its symbolic nature and verbal code; however, experience changes.

Adaptation is a transposition which allows for insignificant deviations from the content-andconceptual aspect of the original text. In such text-transform, the improvised changes in the theme, fable, and image system are acceptable. In the work of fiction, based on the other work, there is a bigger chance of digressing from the plot, theme, and image system of the original text. It entitles us to interpret such texts not as transforms but as the new texts. This is some kind of a transitional form from a text-transform to a completely independent work of fiction. Finally, the plays, based on other creative works, use only selected motives of the original text, while the plot-and-image system is entirely different and independent. Such texts can be seen not as transforms but rather as an allusion to the authentic text. In terms of the genre, when novels and short novels are interpreted, the interference toward comic is taking place; therefore, the proper formats in these transforms are comedy, vaudeville, and farce.

Obviously, the scenery, descriptions, portrait characteristics, speculating, and inside monologues are changed into dialogues, remarks, costumes, and stage decoration. The text-transforms involve a communicative model which makes it possible to use the well-known sources - not only folklore but also fiction. It is tar- 
geted at the intellectual and demanding viewer or listener who will be able to interpret the text, make an analogy, and search for allusions.

The tradition of adaptation of the novels' and short novels' texts was carried on by the Ukrainian dramatist of the early $20^{\text {th }}$ century. Thematic, the plot-and-composition and fine-art transposition of the plots of the famous short novels and novels fall within the general trend of drama's novelisation of this period. It becomes one of the distinguishing communicative strategies of the 20th-century literary process.

In the text, we can observe the implied controversy between, on the one hand, the genre stereotypes of melodrama, folklore-and-ethnographic theatre practices of that period, and, on the other hand, theatre experiments, and the literary processes of the era, as well as the viewer's or reader's expectations.

As N. Maliutina (2006) argues that in the Ukrainian drama of the late $19^{\text {th }}-$ early $20^{\text {th }}$ centuries, "the stage adaptation of the novelistic plots assumed the features of imitation or stylisation of the fantasy-and-mystical conditionality or heroic pathos, theatrical-and-farcical grounding of the plot clichés, and, eventually, parody-andironic travesty or transposition of widely-known plots" (p. 114).

Modernism brought about the new levels of drama communication which can be observed in the works of the Ukrainian dramatists of the 1910s - 1920s. During that period, the dramatists exploit the communicative strategy of the "secondary transformation" in their works. Yu. Lotman, a researcher, defines this strategy as a double-coding resulting in the fact that it is not an original text but rather the stage texts by other authors that become a denotation text. A prose text enters into a complex relationship with the new text, which, according to Yu. Lotman
(2002), creates "text in the text" model (p. 594).

The researcher suggests that "this is a unique rhetoric construct where the difference between the coding of various parts of the text becomes a factor of the author's strategy and reader's perception of the text. Switching from one system of semiotic understanding of the text to the other on an interior structural basis becomes, in this case, the ground for the meaning generation. Such construct escalates the moment of play in the text: from the viewpoint of different ways of coding, the text gains the features of the strong conventionality; it now has a pronounced playful nature, ironic, parody, theatrical content, etc..." (Lotman, 2002, p. 367). As the most straightforward case here, Yu. Lotman spoke about the inclusion of a text segment, coded identically: the picture in the picture, the theatre in the theatre. Double-coding of some segments of the text, which equals the text to the artistic conventionality, deprives the main space of the text of its artistic nature and equalises it to the reality, thus creating the double-theatricalisation effect.

The textual communication of the Ukrainian drama in the 1920 s is related not to the original text, but the adapted one, therefore, why the recipient text allows for the perception (decoding) of other temporal and textual levels that donate to the new text.

Matrix texts do not only contribute to a more extensive repertoire (as in the second part of the $19^{\text {th }}$ century) but also assess the new social reality. They also design the relationships between the government and society, the phenomena of literature and theatre polemic, and experimenting in the art. Besides, such texts also implement the literary strategy of playing with well-known texts, styles, and genres.

Textual communication drove the creative stylisation, grotesque, parody, and allegory on 
those-days principles of the social reality, which, in our opinion, is a display of the double-coding of the newly created texts.

One the most remarkable and quite widelyspread trends in the drama of the early $20^{\text {th }}$ century is stylisation: "The conscious imitation of the creative manner of a writer, formal exterior features of his/her style, certain folklore or literary genre, style, or subgenre" (Volkov, 2001, p. 548). Different types of stylisation and creative techniques are the processes of the internal literary creation; in different texts, they will perform a different function. The stylisation is a feature of the internal text opposition of "someone else's voice vs author's voice" that creates a particular "two-voice texture", where one or the other voice prevails.

To analyse the image creation of the stylised plays, the domain theory by R. Lenecker proves to be instrumental (Kriteva, 1968). Essentially, it suggests that the representation of the knowledge is arranged by the principle of "profile - basis". Such knowledge arrangement enables to code in the language of the characters system at the level of frame semantics. It represents a specific artistic image, realised in the language as elements of both the closed class, comprising grammatical and morphological elements, and the open class, comprising lexical elements. At the level of the open-class items, that is lexical elements, we decode a frame characteristic of the characters, which qualifies them as the participants of the situation, realised in the massive of comedies. When transforming narrative elements, the dramatists employ the strategy of preserving, shortening, extending, and replacement, with the most typical strategy here being shortening. It can be explained by a specific theatrical process and pragmatic orientation on the stage realisation. Meanwhile, extending and replace- ment aim at explication and intensification of the non-regulative relationship between the characters where such relationships already exist and are preserved in the text-transform and are of a non-regulatory nature. Another strategy - a grotesque - is a manifestation of the specific aesthetic tone of the artistic statement. The understanding of the grotesque aesthetic is based on L. Pinskiy's (2013) suggestion that "grotesque in the art is akin to a paradox in logic" (p. 120). Paradoxical nature of the grotesque aesthetic is based on the idea that it is a dialectical denial of the Aristotelian aesthetic. Grotesque implies ambivalent perception of reality in the work of fiction. The author dismembers the reality into the one it really is and the one which, in his opinion, it should be; he shows that the reality is changed (twisted) against its ideal version (Propp, 1968, p. 93).

Therein lies the paradoxical nature of a grotesque representation: a twisted reversal reality alludes to its perfect opposition. Grotesque as a form of exploring reality is particularly widely used in the critical periods of history. Grotesque, according to M. Bakhtin's (1990) definition, is a manifestation of the culture of laughter. V. Meherhold (1968) sees grotesque as a genuinely comic technique of the artistic conventionality in the literature, music, and plastic arts. Grotesque communicates the attitude of the author themself to the world, their perception of reality, where the oppositions are blended (p. 277).

M. Korenevych (2000) believes that grotesque is a type of the artistic imagery that features fantastical ground, a trend toward non-trivial forms, and integration of incompatibles in one object, which is an essential trait of the drama of the first third of the $20^{\text {th }}$ century (p. 12). The communicative strategy of grotesque aims to turn the usual into a miracle. "By distancing the 
reader/viewer and making them watch a certain phenomenon from a side-line, the grotesque hereby brings it to the spotlight and dictates to take it rationally" (Korenevych, 2000, p. 12). The marriage of the tragic and the comic in grotesque is a tool to reach the ultimately generalised and intensified manifestation of the essence of social phenomenon, so, the grotesque becomes an instrument for the creation of the negative assessment of the social reality.

Application of grotesque is apparently determined by the author's desire to transit the viewer from one mode of the artistic imagery to the other, unexpected one; it provides re-coding, switching the message from one mode to the other, even utilising the symbols of other semiotic systems. This transcoding of meanings and content of the statement is driven by grotesque strategy - observed in the plays of Ukrainian dramatists in the 1920s. Despite authors giving reference to the original text, this is just an author's strategy of playing with the viewer. The viewer is familiar with the plays of M. Starytskyi, M. Kropivnytskyi, grounded on the original text. Therefore, we can look at the fact of adaptation, not the original text but instead a text of the theatre coryphées to today's circumstances. This phenomenon of "threading" the thematically related texts is often and nominatively gives the reason to speak about the establishment of a particular textual paradigm of the text-transforms, which is one of the distinguishing features of the new avant-garde art.

In the literature of the 1920 s, the prominent position goes to the author's irony, meant for romanticising the perfect model of the world order; it enhances grotesque, and destruction of such world view and evolves it to the absurd parody.

The action in the plays has a simulating na- ture, associated with the nativity play and complying with the grotesque vision of the author's artistic conventionality. This alliance of the asynchronous events and layers of history and culture creates the parody and ironic effect - on the one side. On the other side, it broadens the frame of the stage space and boosts the development of the dramatic action, based not on the progress of action but on replacing the discourses, space, and mode of the author's vision (the literary discourse replaces the theatrical-and-critical one as well as the discourse of social reality). The $20^{\text {th }}$ century literature process is introduced ironically to the context of performance. The two temporal modes overlap grotesquely: the past and the present with a thinly veiled swipe at the ideological controversies and inconsistency. Another distinguishing feature of an avant-garde play is an indisputable rejection of the tradition and declaration of épater le bourgeois and provocation. Provocation is created through the stage adaptation of other dramatists' works, as well as self-irony, integration of every-day-life and stage reality in one context.

The assessment of today's life in the grotesque and ironically-amusing manner in comical situations and scenes often exposes the author's tragic perception, which makes it fair to speak about tragicomedy. Due to such a combination, the author uses a shifted chronotope, where the events of the past, present, and future echo with one another and are presented as simultaneous. The divorce with the tradition, orientation on the future for the sake of which the present is being ruined, conventional grotesquery, nativity-play dual progress, and tragicomedy make it fair to look at the plays of this period as avant-garde they implement the communicative strategies of the content dimension. Grotesque nature is also manifested in the consolidation of asynchronous 
assessments of the events, both current and retrospective. It allows not only for reproduction the world, people, and their actions from a "stranger's" point of view and assessment - it also accompanies them with the author's remarks and comments. Grotesque is revealed at the level of rejection of the idea of the world's predetermined nature and life's perception where a particular role is acquired once and forever. Theatricality, transferred to life, is artificial and fictitious. However, even a stage performance may have many unnatural, inartistic motives, which also contribute to the grotesque image.

The unreal world opposes to reality, while irony gives the way to sorrow and misery.

The comic trend of the plays is often associated with the collage of both adapted and author's original images that create kind of a pastiche based on stylisation, irony, and grotesque. The analysis of the grotesque strategies in the text-transforms asks for addressing the issues of arrangement of artistic time continuum in the text, for the world is perceived through the time and within the time. According to the accurate observations of academician D. Lickachov (1968), "time is an object, subject, and means (tool) of depicting something" (p. 145). The concept of time is complex. R. Jacobson (1985) analyses the time as a grammar category, thus speaking about grammar time of the artistic work; G. Poulet and H. Meyerhoff believe that the time is the author's response to the modern problems. It seems appropriate to speak about "artistic time continuum": "This is not the view on the problem of time but the time itself as it is reproduced and presented in the work of fiction. This is the essence of the artistic tissue of the literary work which subordinates the work's grammar and philosophic meaning to its tasks" (Likhachov, 1968, p. 79). Time is both the period of creation, i.e. writing the text; but it is also the object, presented in it. The time continuum in the text may be reproduced in close alliance with the historical time or be isolated from it - closed, locked on itself: past, present, and future.

In this condensed, in our opinion, way the time continuum is presented in avant-garde plays of Ukrainian dramatists of the 1920s. The category of the artistic time continuum realised in the communicative model as the information is subject to transformation. It is targeted at the addressee who is also ambiguous in this communicative paradigm and is realised through the variety of subjective perception of this artistic time: it is the depicting of the time, referring to the plot, author, actor, as well as the time of the reader, listener, and viewer. The combinations of the time perception in the work of fiction may vary. Accordingly, the artistic time continuum arranges and drives artistic space, where time is the interrelation of the events. This is the reason why the time is divided into "open" and "closed" (Bakhtin, 1990, p. 81).

"Closed" time is locked on itself and realised within the plot; it does not correlate with the events, taking place beyond the work (text) or with the historical time. "Open" time includes a more extensive time flow, covering a clear and specific historical era. The "open" artistic time does not exclude a clear frame which differs it from reality and implies the possibility of other events beyond the plot (Lakan, 1995). The text may have several time forms, progressing at a different pace. The grammar time and verbal time in the plays of Ukrainian dramatists of that period do not coincide - they are, in fact, quite different. Therefore, all the text details have temporal functions. The time flow is known to depend on how condensed, and tight the manner of presenting the events is. As long as the plays are 
avant-garde, the problem of time in them is realised in quite a specific way, because a work of fiction, separate text or literature trend promote and represent their attitude toward time. This gives us the ground to affirm that the time in all its aspects (factual or presented, plot-related or authorial, of the reader or performer) is a phenomenon of style.

Avant-garde plays provide conventional information about the time as the action takes place in the past, present, or future. For the viewer or reader, the strategy of the author's manipulation with the time creates the illusion of reality, the illusion of "now" (completeness) of the text action. It seems that it is the most accurate way to depict the present time; in other words, it adds significance to the present time. We face a particular paradox here: to create an artistic illusion of the reality, and it takes the present time, which would be ultimately "unplugged" from reality. It should be detached from the author, reader, and performer, and create the effect, the impression of the secondary reality which enables the addressee to completely dip down the text of the work of fiction (Selivanova, 2002).

Such tactic of translating the past into the present is possible in the theatre (stage text) because on the stage, the present theatrical time is the present time of the play, performed before the viewers' eyes. This is a kind of resurrection of time together with events and characters: a resurrection when viewers forget this is the past prior to their time. The dramatists create an illusion of the present, while the author is the person, whose role he plays; he merges with this person in the same manner as the theatrical time merges with the viewers' time in the theatre. Such theatrical present time affects the text, the nature of the characters' phrases, and becomes one of the communicative strategies of the content dimen- sion.

As we can see, the transformation process interferes with the spatial and temporal forms of the original text; it is closely related to the selection of the events and their arrangement in the text-transform. The level of the transformed texts brings about the expanded spatial dimension of the action and macro-time; however, the time continuum of the text is shrinking. The following tactics enable it: inclusion of new episodes - the areas of space where the action in the texts-transforms takes place; the change of the spatial attachment of specific actions, brought from the original text and their attachment to the place of the key events; elimination of the events, developing in the spatial dimensions other than significant events of the storyline of a short novel or novel.

Therefore, having analysed the text of the short novels and novels and the texts-transforms, we can establish the following: 1) the investigated texts create a communicative paradigm which provides the preservation of the significant conceptual and factual information in the text-transform; 2) the specific episodes can be eliminated in the transformed text; however, the implied information (beyond-the-text information, present in the original text) is used as the foundation and allows for transplantation of the heterogenic category of "borders" into the area of the discussion analysis; 3) the transformed texts reveal the significant rearrangement in the consequence of the episodes (chronology) and perspective of presentation of the events; this can be explained by the hierarchy of the cause-and-effect relationship between the events and inclination to the "well-worked play" scheme; 4) if compared to the original text, the information goes through the significant changes; it is revealed through the expansion, reduction, and intensification in the 
transformed texts; 5) in the communicative mod$\mathrm{el}$, the character of this information is influenced jointly by the tradition, modern time, and artistically processed reality. It results in the substantially different arrangement of the dialogic episode in the transformed texts both at the structural and semantic levels. Application of the strategy of grotesque in the text-transforms delivers the limitation of their volume, boosted dynamism, precise sequence of cause-and-effect relationships, explicit nature of the representation of the internal contradictions, pronounced dynamics, pragmatic nature, and oral reproduction.

\section{REFERENCES}

Bakhtin, M. (1990). Tvorchestvo Fransua Rable $i$ narodnaya cul'tura srednevekovia $i$ Renessansa (Creativity Francois Rabelais and Folk Culture Middle Ages and the Renaissance, in Russian). Moscow: Khud. Lit.

Belcerzan, E. (2002). Sprzeeznościowa koncepcja literackosci (Salesian Concept of Literacy, in Polish). In W. Boleckiego \& I R. Nyera (Eds.), Sporne I bersporne problem wspólczesnej wiedzy o literaturze (pp: 38-54). Warsaw: Instytut Badań Literackich PAN. Wydawnictwo.

Jacobson, R. O. (1985). Yazyk v otnoshenii $k$ drugim sistemam kommunikatsii (Language in Terms of Its Relationships with other Systems of Communication, in Russian). In Izbrannye raboty (pp. 319-330). Moscow: Progress.

Kolehaieva, I. M. (2000). Kommunikativnaya paradigma literaturnogo proizvedeniya (kulturologicheskii aspekt) (Communicative Paradigm of a Literary Work (a
Culturological Aspect), in Russian). International Scientific Conference. Linguapax VIII Unerso, 3-B, 547-553.

Kolehaieva, I. M. (2008). Tekstova paradygma mikro-, makro-, giper- I prosto texta (Textual Paradigm of a Micro-, Mega-, Hyper- and Regular Text, in Ukrainian). Zapysky z Romano-Hermanskoi Filolohii, 20, 70-79.

Korenevych, M. (2000). Maska spravzhnia ta uiavna (hrotesknist dramaturhii Mykoly Kulisha) (The Mask True and Ficticious (a Grotesque Nature of Mykola Kulishe's Drama Works), in Ukrainian). Slovo i Chas, 11, 32-37.

Korman, B. (1971). Itogi i perspectivy izucheniia problem avtora (Conclusions and Prospects of Addressing the Author's Issue, in Russian). In D. F. Markov (Ed.), Stranitsy istrorii russkoi literatury (pp. 199-207). Moscow: Science.

Korman, B. (1977). O tselostnosti literaturnogo proizvedeniya (On Cohesive Nature of a Literary Work, in Russian). Izvestiya AN SSR. Seriya literatury I yazyka (News Bulletin of AN SSR. The Section of Literature and Language), 36(6), 508-513.

Kriteva, J. (1968). Por el mes de la structuration $\mathrm{du}$ texte. Nouvelle Critique, Noviembre, $55-64$.

Kukharenko, V. A. (2002). Interpretatsiia tekstu: pidruchnyk dlya stud. Philol. Spets (Text Interpretation: a Textbook for Philological Students, in Ukrainian). Odesa: Latstar.

Lakan, Zh. (1995). Funktsiya i pole rechi v psikhoanalize (Function and Scope of the Speech in Psychoanalysis, in Russian). Moscow: GNOSIS. 
Likhachov, D. S. (1968). Vnutrenniy mir khudozhestvennogo proizvedeniya (The Inner World of a Work of Art, in Russian). Problemy literatury (The Problems of Literature), 8. 74-87.

Lotman, Yu. (2002). Stat'i po semiotike kultury $i$ iskusstva (Articles on Semiotics of Culture and Literature, in Russian). Saint Petersburg: Akademicheskiy Prospekt.

Maliutina, N. P. (2006). Ukrainska dramaturhiia kintsia XIX - pochatku XX stolittia: aspekty rodo-zhanrovoi dynamiky (Ukrainian Drama Works of the Late $19^{\text {th }}-$ Early $20^{\text {th }}$ Century: the Aspects of Genus-Genre Dynamics, in Ukrainian). Odesa: Astroptynt.

Meherhold, V. (1968). O teatre (About Theater, in Russian). Moscow: Iskusstvo.

Pinskiy, L. (2013). Shekspir. Osnovnye nachala dramaturgii (Shakespeare. The Fundamentals of Drama, in Russian). Moscow: Tsentr gumanitarnykh initsiativ.
Propp, V. (1968). Morfologiya skazki (Fairytale Morphology, in Russian). Moscow: Nauka.

Riffaterre, M. (1980). Kriterii stilisticheskogo analiza (Criteria of Stylistic Analysis, in Russian). Novoe $v$ zarubezhnoi lingvistike (Latest Advances in Foreign Linguistics), $I X, 69-97$.

Selivanova, O. A. (2002). Osnovy lingvisticheskoi teorii teksta i kommunikatsii [Monograficheskoie uchebnoie posobie] (Fundamentals of the Linguistic Theory of Text and Communication [Monographic textbook], in Ukrainian). Kyiv: Izd-vo Ukr. Fitosotsiologicheskogo tsentra.

Volkov, A. (Ed.) (2001). Leksikon zahalnoho ta porivnialnoho literaturoznavstva (Lexicon of General and Comparative Literature Steadies, in Ukrainian). Chertnivtsi: Zoloti Litavry. 